\title{
Efek Hepatoprotektif Bit Merah (Beta vulgaris L) Organik terhadap Abnormalitas Faal Hepar Akibat Paparan Pestisida
}

\section{The Effect Hepatoprotective Of Organik Beetroot (Beta vulgaris L) On Faal Hepar Abnormality Due To Pesticide Exposure}

\author{
Kartika Ikawati $^{1}$, Agus Widodo ${ }^{2}$ \\ Jurusan Analis Kesehatan, Akademia Analis Kesehatan 17 Agustus 1945 Semarang, Indonesia
}

\section{ARTICLE INFO}

\section{Article history}

Received date

08 Feb 2021

Revised date

21 Apr 2021

Accepted date

23 Apr 2021

\section{Keywords:}

Beetroot organic;

Liver;

Pesticides.

Kata kunci:

Bit merah organik;

Hepar;

Pestisida.

\author{
ABSTRACT/ ABSTRAK
}

Pesticide exposure causes hepatic parenchymal cell damage and impaired hepatic membrane permeability. Organic red beets contain high levels of flavonoids, betanin, and polyphenols. The phytochemical compounds in beetroot are anti-inflammatory, antioxidant, and antihepatotoxicity. The purpose of this study was to determine the hepatoprotective effect of organic beetroot (Beta vulgaris $L$ ) on hepar physiological abnormalities due to exposure to pesticides. This type of research is an experiment with Post Test Only Randomized Control Group Design. The study population was male Wistar rats aged 2-3 months with a weight of 150-200g. The sampling technique was randomly assigned to 30 rats were divided into 6 groups. Beetroot ethanol extract intake and pesticide exposure were observed for 14 days. Liver physiological abnormalities were measured based on the levels of the enzyme cholinesterase, Gamma GT, SGOT, and SGPT. Measurement of enzymes using the IFCC method, using Stardust MC15 and Humalyzer spectrophotometer. Data analysis using Anova test. There was a hepar physiological abnormality after pesticide exposure which was indicated by a significant decrease in the cholinesterase enzyme ( $p$-value $=0,000)$ and a significant increase in the Gamma GT, SGOT, and SGPT enzymes (p-value=0,000). The intake of organic beetroot ethanol extract (Beta vulgaris L) significantly increased the cholinesterase enzyme back ( $\mathrm{p}$-value $=0,000)$ and significantly decreased the Gamma GT, SGOT, and SGPT enzymes (p-value $=0,000)$, approaching normal levels at a dose of $400 \mathrm{mg} / \mathrm{kgBW}$. Organic red beetroot (Beta vulgaris $L$ ) has a hepatoprotective effect on hepar physiological abnormalities due to exposure to pesticides.

\begin{abstract}
Paparan pestisida menyebabkan kerusakan sel parenkim hepar dan gangguan permeabilitas membran hepar. Bit merah organik mempunyai kandungan flavonoid, betanin dan pholipenol yang tinggi. Senyawa fitokimia dalam bit merah bersifat anti inflammatory, antioxidant dan antihepatotoxicity. Tujuan penelitian ini untuk mengetahui efek hepatoprotektif bit merah (Beta vulgaris L) organik terhadap abnormalitas faal hepar akibat paparan pestisida. Jenis penelitian adalah eksperimen dengan rancangan Post Test Only Randomized Control Group Design. Populasi penelitian tikus jantan galur Wistar umur 2-3 bulan dengan berat badan 150-200g. Teknik sampling secara random terhadap 30 tikus yang dibagi menjadi 6 kelompok. Asupan ekstrak etanol bit merah dan paparan pestisida diamati selama 14 hari. Abnormalitas faal hepar diukur berdasarkan kadar enzim cholinesterase, Gamma GT, SGOT dan SGPT. Pengukuran enzim dengan metode IFCC, menggunakan alat spektrofotometer Stardust MC15 dan Humalyzer. Analisis data dengan uji Anova. Didapatkan adanya abnormalitas faal hepar setelah paparan pestisida yang ditandai dengan penurunan bermakna enzim cholinesterase $(p$-value $=0,000)$ dan peningkatan bermakna enzim Gamma GT, SGOT dan SGPT ( $p$-value=0,000). Asupan ekstrak etanol bit merah (Beta vulgaris L) organik meningkatkan kembali enzim cholinesterase secara bermakna $(p$-value $=0,000)$ dan penurunan bermakna terhadap enzim Gamma GT, SGOT dan SGPT ( $p$-value $=0,000)$, mendekati level normal pada dosis $400 \mathrm{mg} / \mathrm{KgBB}$. Bit merah (Beta vulgaris $\mathrm{L}$ ) organik memiliki efek hepatoprotektif tehadap abnormalitas faal hepar akibat paparan pestisida.
\end{abstract}

Corresponding Author:

Kartika Ikawati

Jurusan Analis Kesehatan, Akademi Analis Kesehatan 17 Agustus 1945 Semarang, Indonesia Email: kartika.aisha@yahoo.com 


\section{PENDAHULUAN}

Saat ini penggunaan pestisida oleh petani tidak dapat dihindarkan lagi (Suripto, 2017). Dengan alasan optimalisasi, penggunaannya sering tidak sesuai aturan dengan mencampur beberapa jenis pestisida menjadi satu dan dengan dosis berlebih. Kondisi ini tentunya membahayakan bagi lingkungan dan kesehatan manusia (Gangemi, et al., 2016). Empat golongan pestisida yang sering digunakan di bidang pertanian yaitu; organofosfat, karbamat organoklorin, dan piretroid. Golongan pestisida ini bersifat toksik bagi manusia jika digunakan berlebihan dalam waktu yang lama (Badan Litbangkes RI, 2013). Paparan akut campuran beberapa jenis pestisida sama bahayanya dengan paparan tunggal jangka panjang (Fantke, et al., 2012; Ramírez-Santana, et al., 2018).

Hati atau hepar merupakan salah satu organ target racun pestisida (Ganong, 2008). Pestisida golongan karbamat dan organophospat dapat menghambat kerja enzim cholinesterase (ChE) dalam darah (Bendetti, 2014). Kadar enzim asetilkolinesterse (AChE) dan cholinesterse (ChE) dapat digunakan sebagai indikator adanya keracunan pestisida dalam darah (Lionetto, et al., 2013). Pestisida akan terakumulasi dalam hepar, menyebabkan kerusakan sel parenkim hepar dan gangguan permeabilitas membran hepar yang ditandai dengan peningkatan enzim dalam darah (Ganong, 2008; Silvério, et al., 2017). Abnormalitas faal hepar mengakibatkan enzim yang dihasilkan oleh hepar bebas keluar sehingga meningkatkan enzim aminotransferase dalam darah (Guyton, 2014). Indikator adanya abnormalitas hepar diukur dari kadar enzim cholinesterase, serum glutamic oxsaloasetic transaminase (SGOT), serum glutamic pyruvic transaminase (SGPT) dan Gamma glutamil transferase/Gamma GT (ElGengaihi, et al., 2016; Rose, et al., 2014).

Bit merah kaya mineral dan vitamin serta senyawa fitokimia seperti asam askorbat, karotenoid, asam fenolik, flavonoid, terponoid, steroid, tanin dan saponin (Clifford, et al., 2015). Flavonoid, betanin dan pholipenol mempunyai kemampuan sebagai antioksidan (Carrillo, et al., 2017). Beberapa penelitian membuktikan bit merah mempunyai kemampuan sebagai anti inflammatory, antioxidant dan mempunyai efek antihepatotoxicity (Kim, et al., 2020), Penelitian (Clifford, et al., 2015) mendapatkan ekstrak metanol bit merah memiliki kandungan fenolik dan flavonoid masing-masing 39,75mgGAE/g dan $20,73 \mathrm{mgCE} / \mathrm{g}$ yang menunjukkan aktivitas antioksidan tinggi serta tidak memiliki genotoksisitas atau efek sitotoksik. Kandungan phenolic, flavonoid dan total antioxidant capacities dalam bit merah mempunyai kemampuan memproteksi hepar atau disebut hepatoprotektif (Guldiken, et al., 2016; Coles \& Clifton, 2012; Krajka-Kuźniak, et al., 2012). Di dalam $100 \mathrm{~g}$ bit merah terkandung $128,7 \mathrm{mg}$ betalain. Betalain merupakan antioksidan tinggi yang berfungsi sebagai anti radikal bebas, memberikan perlindungan terhadap stres oksidatif dan pembersih racun kimia (Nemzer, et al., 2011; Kumar, 2015).

Umbi bit merah yang ditanam dengan cara organik mempunyai kandungan total betalain dan polifenol yang lebih tinggi dibandingkan cara tanam non organik. Rata-rata bit organik mengandung betalain 32\% lebih tinggi dibanding bit non organik dan kandungan polifenol 20-52\% lebih tinggi dibanding non organik. Cara tanam organik memungkinkan bit merah mempunyai kemampuan antioxidan yang lebih tinggi dibanding cara tanam non organik (Carrillo, et al., 2019). Cara tanam organik adalah budidaya tanaman menggunakan bahan-bahan alami tanpa menggunakan bahan kimia sintesis sebagi pupuk atau pembunuh hama.

Beberapa penelitian terkait keracunan pestisida yaitu; penelitian dari Siwiendrayanti, mendapatkan 23,3\% wanita usia subur di Kersana Brebes yang terpapar pestisida mengalami gangguan fungsi hati dengan risiko 1,3 kali lebih tinggi (Tsani, et al., 2017). Penelitian pada petani di Desa Sengon, Brebes mendapatkan 65,28\% mengalami keracunan pestisida (Kartika, 2012). Pajanan pestisida 10-50 kali menyebakan penurunan yang signifikan terhadap enzim asetilkolinestrase (Hernández, et al., 2006). Penelitian sebelumnya membuktikan kerusakan profil darah dapat diperbaiki oleh bit merah dengan dosis optimal $400 \mathrm{mg} / \mathrm{KgBB}$. Bit merah dapat meningkatkan Indek Eritrosit secara signifikan pada mahasiswa dengan anemia $(p$ value $<0,05$ ) (Ikawati \& Rokhana, 2018). Penelitian Rose, et al., (2014), mendapatkan hasil ekstrak metanol bit merah $300 \mu \mathrm{gm} / \mathrm{ml}$, dapat memperbaiki kondisi hepatotoksisitas yang disebabkan Carbon Tetraclorida (CCl4). Sedangkan penelitian Wulandari (2019), terhadap petani yang terpapar pestisida mendapatkan hasil bahwa konsumsi jus bit merah sebanyak 500ml, dua hari sekali selama 2 bulan dapat meningkatkan kadar cholinesterase tetapi tidak signifikan. Penelitian Wulandari tidak menjelaskan jenis bit merah organik atau non organik.

Perbedaan penelitian ini dengan penelitian sebelumnya terletak pada populasi, paparan 
bahan kimia, bentuk olahan bit merah dan jenis pemeriksaan darah. Perbedaan penelitian ini dengan penelitian yang mendekati yaitu Rose, et al (2014), terletak pada paparan bahan kimia dan ekstrak yang digunakan. Penelitian Rose, et al menggunkan paparan CCL4 dan ekstrak metanol sedangkan pada penelitian ini menggunakan campuran 3 jenis pestisida dan ekstrak etanol. Perbedaan dengan penelitian Wulandari terletak pada populasi, bentuk olahan bit merah dan parameter pemeriksaan darah. Populasi pada penelitian Wulandari (2019) adalah petani yang diberi perlakuan konsumsi jus bit merah dengan parameter pemeriksaan cholinesterase. Sedangkan penelitian ini menggunkan populasi tikus yang diberi perlakuan konsumsi bit merah organik dalam bentuk ekstrak etanol dengan parameter pemeriksaan cholinesterase, Gamma GT, SGOT dan SGPT.

Tujuan penelitian ini untuk mengetahui efek hepatoprotektif bit merah (Beta vulgaris L) organik terhadap abnormalitas faal hepar akibat paparan pestisida. Paparan pestisida pada penelitian ini dalam bentuk campuran tiga jenis pestisida, agar menyerupai kebiasaan yang dilakukan oleh petani. Sedangkan dipilihnya bit merah organik, agar perbaikan terhadap abnormalitas faal hepar lebih optimal. Untuk mengetahui pengaruhnya terhadap faal hepar dilakukan pengukuran terhadap enzim cholinesterase, enzim Gamma glutamil transferase (GGT), Serum glutamic oxsaloaseticttransaminase (SGOT) atau yang dikenal dengan aspartate aminotransferase (AST) dan serum glutamic pyruvic transaminase (SGPT) atau alanine aminotransferase (ALT) (Rose, et al., 2014). Manfaat dari penelitian ini untuk memberikan informasi bahwa bit merah organik dapat digunakan sebagai kandidat sumber zat bioaktif baru untuk perbaikan abnormalitas faal hepar khususnya karena paparan pestisda.

\section{METODE}

Jenis penelitian ini adalah eksperimen dengan rancangan post test only randomized control group design. Penelitian ini sudah mendapatkan izin etik dari Komisi Bioetika Penelitian Kedokteran/Kesehatan, Fakultas Kedokteran UNISSULA Semarang dengan No.365/XI/2020/Komisi Bioetik. Populasi penelitian menggunakan tikus jantan galur Wistar yang berumur 2-3 bulan dengan berat badan 150$200 \mathrm{~g}$. Sampel penelitian sebanyak 30 tikus yang dibagi menjadi 6 kelompok yang dihitung dengan rumus Federer. Setiap kelompok terdiri dari 5 tikus yang dipilih secara random. Bit merah (Beta vulagris $L$ ) organik didapatkan dari pertanian organik Tranggulasi Kopeng Salatiga. Pestisida yang digunakan untuk paparan yaitu; Dursband 200EC (organofosfat), Antracol 70WP, dan Mancozeb (karbamat). Pembuatan ekstrak etanol bit merah dilakukan di Laboratorium Farmasi Fakultas Kedokteran UNISSULA Semarang. Determinasi bit merah dan perlakuan hewan uji dilakukan di Fakultas MIPA UNNES Semarang pada bulan Juli tahun 2020. Hasil identifikasi tumbuhan bit yang digunakan termasuk familia Chenopodiaceae, genus Beta, spesies Beta vulgaris $L$, var Beta vulgaris $L$. var. rubra (L) Moq, vern name Bit merah/Common beet. Pemeriksaan parameter faal hepar pada penelitian ini dilakukan di Balai Laboratorium Kesehatan Provinsi Jawa Tengah dan di Laboratorium Klinik Akademi Analis Kesehatan 17 Agustus 1945 Semarang. Pembuatan ekstrak umbi bit merah dengan metode remaserasi. Sebanyak $300 \mathrm{~g}$ bubuk bit dimaserasi dengan etanol $3.000 \mathrm{ml}(1: 10)$ dalam wadah dan dishaker 2 hari pada suhu ruang. Hasil maserasi disaring dengan kertas saring Wattman no 1 dan diuapkan dengan freeze dryer selama $4 \times 24$ jam. Ekstrak kemudian diencerkan dengan aquades konsentrasi $100 \mathrm{mg} / \mathrm{KgBB}, \quad 200 \mathrm{mg} / \mathrm{KgBB}$, dan $400 \mathrm{mg} / \mathrm{KgBB} \quad$ (Indhumathi \& Kannikaparameswari, 2012). Pencampuran pestisida yaitu; sebanyak 3ml Dursband, 29ml Antracol dan 4g Mancozeb, dicampur menjadi satu kemudian dilarutkan dengan aquadest ad 1L.

Tahap awal dari percobaan ini dimulai dengan penimbangan berat badan dan randomisasi tikus. Semua kelompok tikus terlebih dahulu diaklimatisasi selama 7 hari dan diberi pakan standar secara ad libitum selama percobaan berlangsung. Tikus dipuasakan selama 60 menit, sebelum percobaan dimulai. Adapun perlakuan terhadap 6 kelompok tikus yaitu: kelompok I (kontrol normal) tikus hanya diberi pakan pelet standar saja. Kelompok II (kontrol negatif) tikus diberi ekstrak bit merah $100 \mathrm{mg} / \mathrm{KgBB}$. Kelompok III (kontrol positif) tikus diberi paparan pestisida tanpa diberi ekstrak bit merah. Pada kelompok IV atau (eksperimen 1) tikus diberi paparan pestisida dan ekstrak bit merah organik $100 \mathrm{mg} / \mathrm{KgBB}$. Kelompok V (eksperimen 2) tikus diberi paparan pestisida dan ekstrak etanol bit merah organik $200 \mathrm{mg} / \mathrm{KgBB}$. Pada kelompok VI (eksperimen 3) tikus diberi paparan pestisida dan ekstrak etanol bit merah organik $400 \mathrm{mg} / \mathrm{KgBB}$. Asupan bit merah dan paparan pestisida dimulai pada hari ke-8 sampai hari ke-21. Paparan pestisida sebanyak $140 \mathrm{ml}$ 
pada kelompok III, IV, V dan VI dilakukan setiap hari di ruang tertutup dengan luas $9 \mathrm{~m}^{2}$, dengan alat sprayer. Asupan estrak etanol Beta vulgaris $L$ pada kelompok II, IV, V dan VI dilakukan secara per oral dengan interval 24 jam. Pada hari ke 22 dilakukan pengambilan darah di plexus retro orbitalis, kurang lebih $3 \mathrm{ml}$ tanpa antikoagulan untuk dibuat serum. Syarat serum yang baik berwarna kuning jernih tidak lisis ataupun lipemik (Hoffbrand \& Moss, 2016). Serum kemudian digunakan untuk pemeriksaan enzim cholinesterase dengan menggunakan metode Kinetic Photometrik Test. Pemeriksaan Gamma GT, SGOT dan SGPT dengan metode International Federation of Clinical Chemistry and Laboratory Medicine (IFCC). Alat yang digunakan untuk pemeriksaan tersebut yaitu spektrofotometer Stardust MC15 dan Humalyzer. Data kemudian dianalisis dengan uji ANOVA dan Post Hoc.

\section{HASIL}

Tabel 1. Rata-Rata Kadar Cholinesterase, Gamma GT, SGOT/AST dan SGPT/ALT

\begin{tabular}{lrrrrrr}
\hline & \multicolumn{7}{c}{ Rata-rata \pm SD (U/L) } \\
\cline { 2 - 7 } Parameter & \multicolumn{1}{c}{ Kel I } & \multicolumn{1}{c}{ Kel II } & \multicolumn{1}{c}{ Kel III } & \multicolumn{1}{c}{ Kel IV } & \multicolumn{1}{c}{ Kel V } & \multicolumn{1}{c}{ Kel VI } \\
\hline Cholinesterase & $172,60 \pm 17,95$ & $227,40 \pm 8,20$ & $94,20 \pm 8,64$ & $98,00 \pm 11,25$ & $159,80 \pm 34,22$ & $193,40 \pm 20,27$ \\
Gamma GT & $2,74 \pm 0,39$ & $2,59 \pm 0,28$ & $5,75 \pm 0,47$ & $4,11 \pm 0,77$ & $3,06 \pm 0,63$ & $2,39 \pm 0,19$ \\
SGOT/AST & $81,40 \pm 9,79$ & $82,80 \pm 8,65$ & $123,16 \pm 6,08$ & $92,96 \pm 10,94$ & $84,18 \pm 5,54$ & $76,60 \pm 6,35$ \\
SGPT/ALT & $56,74 \pm 3,57$ & $46,42 \pm 3,36$ & $90,02 \pm 5,86$ & $71,71 \pm 6,14$ & $64,98 \pm 5,64$ & $59,25 \pm 6,58$ \\
\hline
\end{tabular}

Data tabel 1 diketahui bahwa kadar cholinesterase paling tinggi terdapat pada kelompok II atau kelompok kontrol negatif. Pada kelompok ini tikus hanya diberi asupan ekstrak etanol bit merah tanpa paparan pestisida. Kadar cholinesterase kelompok III turun sebesar $45,4 \%$ jika dibandingkan kelompok I dan turun sebesar $58,58 \%$ jika dibandingkan kelompok II. Pada kelompok III ini tikus hanya diberi paparan pestisida. Kadar cholinesterase kembali meningkat setelah tikus diberi asupan ekstrak etanol bit merah organik (kelompok IV, V dan VI). Semakin banyak asupan ekstrak etanol bit merah yang diberikan maka kenaikan enzim cholinesterase semakin tinggi. Kadar cholinesterase pada kelompok VI kembali pulih menyerupai kelompok I (kontrol normal).

Hasil pengukuran enzim Gamma GT dan SGPT/ALT paling rendah didapatkan pada kelompok II. Kadar Gamma GT, SGOT dan SGPT didapatkan paling tinggi pada kelompok tikus yang hanya dipapar pestisida (kelompok III). Setelah dipapar pestisida kadar Gamma GT pada kelompok III naik 109,9\% jika dibanding kelompok I dan naik $122 \%$ jika dibandingkan kelompok II. Demikian juga untuk kadar SGOT dan SGPT pada kelompok III, terjadi kenaikan hampir 2 kali lipat (48\%) jika dibanding kelompok I dan II. Tetapi kadar enzim tersebut kembali turun setelah diberi asupan ekstrak etanol bit merah (kelompok IV, V dan VI). Kadar Gamma GT, SGOT dan SGPT pada kelompok VI kembali pulih mendekati kadar kelompok I (kontrol normal). Penurunan Kadar Gamma GT kelompok IV, V dan VI dibanding kelompok III berturut-turut; $28,5 \%, 46,78 \%, 58,4 \%$. Kadar

Gamma GT pada kelompok VI turun dua kali lipat dibanding kelompok III. Penurunan kadar enzim SGOT kelompok IV, V dan VI dibanding kelompok III berturut-turut; $24,5 \%$, $31,6 \%, 37,8 \%$. Dan penurunan kadar SGPT kelompok IV, V dan VI dibanding kelompok III masing-masing 20,3\%, 27,81\% dan 34,18\%.

Untuk memudahkan membedakan hasil pengukuran kadar enzim tiap kelompok dapat dilihat pada gambar 1, 2, 3 dan 4 berikut ini:

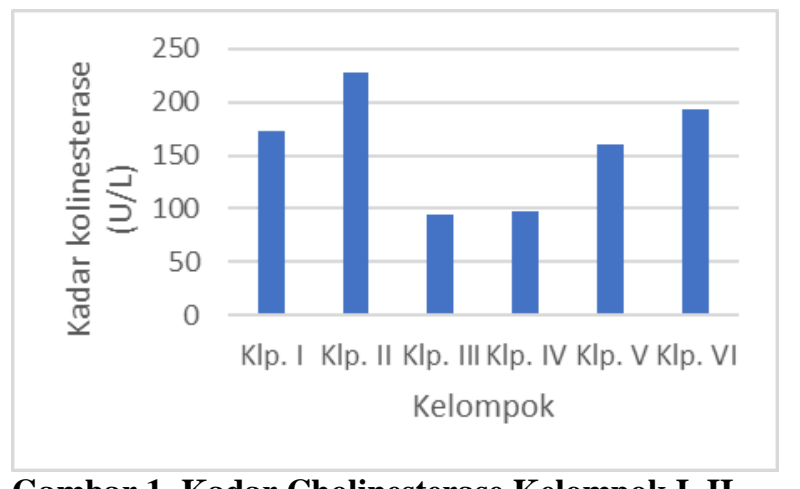

Gambar 1. Kadar Cholinesterase Kelompok I, II III, IV,V dan VI

Pada gambar 1 diketahui kadar cholinesterase paling tinggi pada kelompok II (hanya diberi ekstrak bit) dan paling rendah pada kelompok III (hanya dipapar pestisida). 


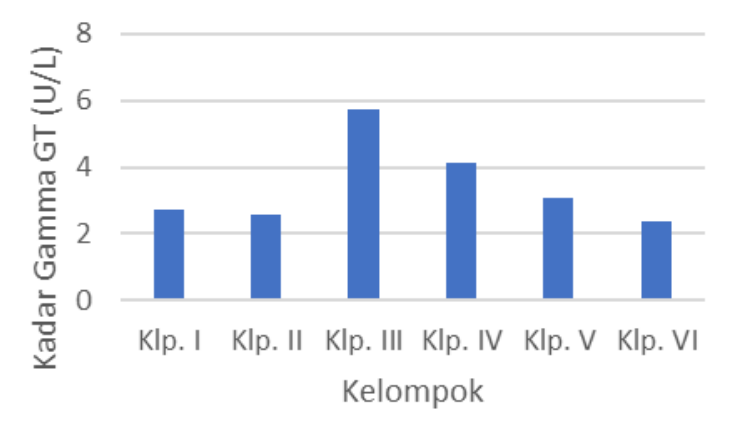

Gambar 2. Kadar Gamma GT Kelompok I, II, III IV, V dan VI

Pada gambar 2 diketahui kadar Gamma GT paling rendah pada kelompok II (hanya diberi ekstrak bit) dan Paling tinggi pada kelompok III (hanya dipapar pestisida).

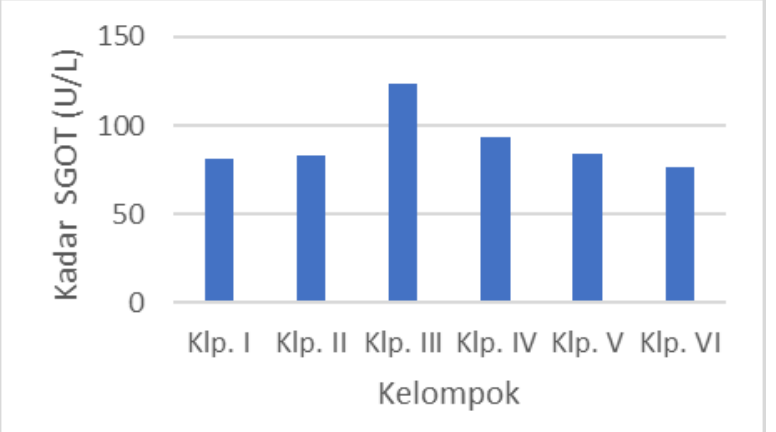

Gambar 3. Kadar SGOT Kelompok I, II, III, IV V dan VI

Tabel 2. Hasil Uji Normalitas Data dan Uji ANOVA Enzim Cholinesterase, Gamma GT, SGOT dan SGPT pada Hewan Uji

\begin{tabular}{lccccrcrr}
\hline Parameter (U/L) & \multicolumn{4}{c}{ Uji Normalitas Data ( p/sig) } & \multicolumn{2}{c}{ Uji Homogenitas } & Uji Anova \\
\cline { 2 - 9 } & Kel 1 & \multicolumn{1}{c}{ Kel 2 } & \multicolumn{1}{c}{ Kel 3 } & \multicolumn{1}{c}{ Kel 4 } & \multicolumn{1}{c}{ Kel 5 } & Kel 6 & (sig) & \\
\hline Cholinesterase & 0,083 & 0,803 & 0,839 & 0,161 & 0,225 & 0,818 & 0,233 & 0,000 \\
Gamma GT & 0,425 & 0,051 & 0,241 & 0,17 & 0,173 & 0,246 & 0,1 & 0,000 \\
SGOT & 0,811 & 0,168 & 0,683 & 0,245 & 0,31 & 0,931 & 0.367 & 0,000 \\
SGPT & 0,278 & 0,611 & 0,058 & 0,496 & 0,463 & 0,665 & 0,623 & 0,000 \\
\hline
\end{tabular}

Dari tabel 2, diketahui bahwa semua kelompok berdistribusi normal dan homogen $p$ value $>0,05$. Hasil analisis ANOVA mendapatkan nilai $p$-value $=0,000(<0,05)$ baik pada parameter cholinesterase, Gamma GT, SGOT maupun SGPT. Hal ini dapat diinterpretasikan bahwa paling tidak terdapat perbedaan kadar yang bermakna pada lebih dari
Pada gambar 3 diketahui bahwa kadar SGOT paling rendah pada kelompok I (Kontrol normal) dan paling tinggi pada kelompok III (hanya dipapar pestisida).

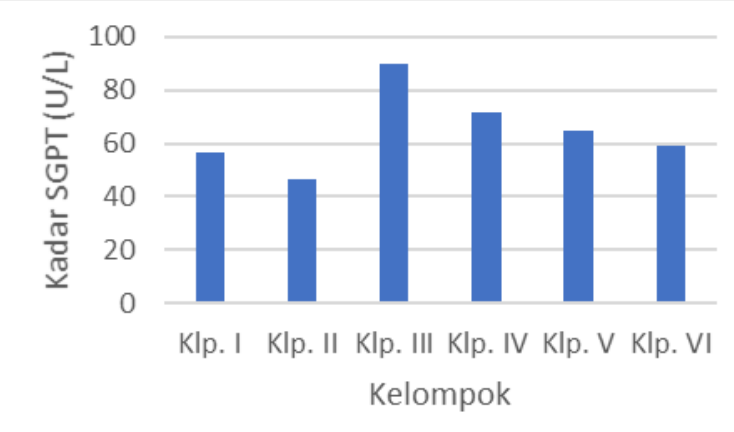

Gambar 4. Kadar SGPT Kelompok I, II, III, IV,V dan VI

Pada gambar 4 diketahuai bahwa kadar SGPT terendah pada kelompok II (hanya diberi ekstrak bit) dan Tertinggi pada kelompok III (hanya dipapar pestisida).

Dari gambar 1-4 dapat diketahui bahwa semakin tinggi dosis asupan ekstrak bit merah, maka semakin tinggi prosentase peningkatan enzim cholinesterase dan semakin banyak penurunan enzim Gamma GT, SGOT dan SGPT.

Sebelum dilakukan analisis, data diuji normalitas dan homogenitas. Selanjutnya dilakukan analisis data dengan uji ANOVA. dua kelompok data. Untuk mengetahui pada kelompok mana saja terjadi perbedaan yang bermakna maka dilakukan uji Post Hoc. Pada penelitian ini digunakan kelompok III sebagai pembanding terhadap penurunan fungsi faal hepar dan kemampuan ekstrak etanol bit merah (Beta vulgaris L) organik dalam perbaikan abnormalitas faal hepar. 
Tabel 3. Uji Post Hoc Enzim Cholinesterase, Gamma GT, SGOT dan SGPT pada Hewan Uji

\begin{tabular}{llr}
\hline Jenis Enzim & Kelompok & Sig. \\
\hline & Kelompok 1 (K.Neg) &, 000 \\
Cholinesterase. & Kelompok 2 (K.Pos.1) &, 000 \\
Kelompok 3 & Kelompok 4 (Tes.100 mg) & 1,000 \\
(Kontrol Pos.2) & Kelompok 5 (Tes.200 mg) &, 000 \\
& Kelompok 6 (Tes.400 mg) &, 000 \\
& Kelompok 1 (K. Neg) &, 000 \\
Gamma GT. & Kelompok 2 (K.Pos.1) &, 000 \\
Kelompok 3 & Kelompok 4 (Tes.100 mg) &, 000 \\
(Kontrol Pos.2) & Kelompok 5 (Tes.200 mg) &, 000 \\
& Kelompok 6 (Tes.400 mg) &, 000 \\
& Kelompok 1 (K. Neg) &, 000 \\
SGOT. & Kelompok 2 (K.Pos.1) &, 000 \\
Kelompok 3 & Kelompok 4 (Tes.100 mg) &, 000 \\
(Kontrol Pos.2) & Kelompok 5 (Tes.200 mg) &, 000 \\
& Kelompok 6 (Tes.400 mg) &, 000 \\
& Kelompok 1 (K. Neg) &, 000 \\
SGPT. & Kelompok 2 (K.Pos.1) &, 000 \\
Kelompok 3 & Kelompok 4 (Tes.100 mg) &, 000 \\
(Kontrol Pos.2) & Kelompok 5 (Tes.200 mg) &, 000 \\
& Kelompok 6 (Tes.400 mg) &, 000 \\
\hline
\end{tabular}

Dari tabel 3 diketahui hasil uji post hoc didapatkan adanya perbedaan yang bermakna pada semua kelompok parameter cholinesterase, Gamma GT, SGOT dan SGPT dibanding kelompok III, ( $p$-value $=0,000)$ kecuali pada parameter kolonesterase antara kelompok III dan kelompok IV tidak didapatkan perbedaan bermakna ( $p$-value $=1,000)$. Hasil penelitian menunjukkan bahwa pestisida dikaitkan dengan penurunan sebesar $50 \%$ terhadap enzim cholinesterase dan peningkatan dua kali lipat terhadap aktivitas Gamma GT, serum glutamic oxsaloasetic transaminase (SGOT) dan serum glutamic pyruvic transaminase (SGPT) dibanding kelompok kontrol normal (p-value $<0,05)$. Asupan ekstrak etanol bit merah organik memulihkan cholinesterase, enzim Gamma GT, SGOT dan SGPT. Kadar cholinesterase meningkat secara signifikan ( $p$-value $=0,000)$ setelah pemberian ekstrak etanol bit merah organik 200mg/Kg BB (kelompok V) dan $400 \mathrm{mg} / \mathrm{KgBB} \quad$ (kelompok VI) dibanding kelompok III. Asupan ekstrak etanol bit merah organik menurunkan enzim Gamma GT, SGOT dan SGPT secara signifikan $(p$-value $=0,000)$ pada semua kelompok eksperimen (IV, V dan VI) dibanding kelompok III (kontrol positif).

\section{PEMBAHASAN}

Pada penelitian ini terbukti paparan pestisida sebanyak $140 \mathrm{ml} /$ hari selama 14 hari menyebabkan penurunan terhadap enzim cholinesterase. Hal ini ditunjukkan dengan adanya penurunan enzim cholinesterase yang signifikan pada kelompok III dibandingkan kelompok I (kontrol normal) dan kelompok II (kontrol negatif) dengan $p$-value $=0,000$. Hasil penelitian ini sejalan dengan penelitian Khan, et al. (2008), yang melaporkan adanya penurunan aktivitas plasma Butyrylcholinesterase (BChE) pada petani tembako di Pakistan yang terpapar pestisida ( $p$-value<0,001). Bendetti (2014) melaporkan adanya efek penurunan aktivitas cholinesterase pada paparan campuran pestisida dosis rendah yang berulang dan berkepanjangan. Shentema, et al. (2020) melakukan penelitian tehadap populasi petani perkebunan dan mendapatkan prevalensi yang tinggi terhadap abnormalitas cholinesterase. Penelitian ini juga sejalan dengan Ramírez-Santana, et al., dalam penelitiannya di Chile tahun 2018 mendapatkan hasil bahwa terjadi penghambatan asetilkolinesterse (AChE) pada 55\% dari kelompok petani yang terpapar pestisida di tempat kerjanya.

Silvério, et al., (2017) mengatakan bahwa aktifitas enzim cholinesterase plasma atau serum merupakan indikator yang lebih baik terhadap toksisitas pestisida akut daripada AChE eritrosit untuk menilai eksposur akut organopospat. Penurunan enzim cholinesterase dalam serum dapat digunakan sebagai indikator adanya keracunan pestisida (Bendetti, 2014). Cholinesterase adalah famili enzim pada cairan seluler yang berfungsi mengkatalisis hidrolisis asetilkoline ( $\mathrm{ACh})$ menjadi kolin dan asam asetat (Lionetto, et al., 2013). Asetilkolin berfungsi sebagai penghantar rangsang syaraf (neurotransmitter) yang terdapat pada sistem saraf pusat, saraf otonom dan saraf somatik. Pestisida terutama karbamat dan organopospat merupakan inhibitor cholinesterase yang mampu membentuk ikatan sangat stabil dan irreversibel terhadap asetilkolineseterase (Bendetti, 2014). Ketika terjadi paparan pestisida dan masuk ke dalam tubuh melalui inhalasi, maka pestisida akan mengikat enzim cholinesterase. Akibat dari ikatan tersebut katalisis hidrolisis asetilkolin terblokir. Hal ini menyebabkan kadar cholinesterase dalam darah berkurang tetapi kadar aseilcholinesterase meningkat. Paparan pestisida yang berlebihan menyebabkan perubahan sitotoksik pada penanda biokimia hati dan ginjal 
yang berkorelasi positif dengan residu pestisida (Lionetto, et al., 2013; Silvério, et al., 2017).

Pada penelitian ini kadar cholinesterase meningkat secara signifikan $(p$-value $=0,000)$ setelah pemberian ekstrak beet $200 \mathrm{mg} / \mathrm{Kg}$ BB (kelompok V) dan 400mg/KgBB (kelompok VI). Pemberian ekstrak bit 100 mg/Kg BB (kelompok IV) belum bisa memberikan peningkatan cholinesterase yang signifikan. Hal ini kemungkinan karena dosis yang kecil. Peningkatan kembali kadar cholinesterase menunjukkan fungsi hepar mulai membaik. Hasil yang berbeda didapatkan dari penelitian Wulandari terhadap petani yang terpapar pestisida mendapatkan hasil bahwa konsumsi jus bit merah sebanyak $500 \mathrm{ml}$ dua hari sekali selama 2 bulan dapat meningkatkan kadar kolinesterse tetapi tidak signifikan. Penelitian Wulandari kemungkinan tidak menggunakan bit organik dan dikonsumsi dalam bentuk jus, sehingga peningkatan kadar cholinesterase tidak signifikan (Wulandari, 2019). Penelitian ini menggunakan buah bit dalam bentuk ekstrak. Ekstraksi menyebakan sebagian besar zat aktif seperti flavonoid, betanin dan pholipenol terisolasi. Ekstraksi menyebabkan kandungan metabolit sekunder yang berkhasiat obat di ekstrak semua secara optimal. Sedangkan pada bentuk jus masih ada fiber yang berlebihan yang tidak berkhasiat.

Penelitian ini juga mendapatkan peningkatan yang signifikan terhadap kadar Gamma GT, SGOT dan SGPT pada kelompok tikus yang terpapar pestisida. Ganong mengatakan bahwa akumulasi pestisida dalam hati tidak dapat diekskresikan dan tetap tersimpan dalam hati (Ganong, 2008). Hal ini mengakibatkan kerusakan parenkim hati dan gangguan permeabilitas membran hati serta berdampak pada peningkatan enzim transaminase dalam darah. Peningkatan Enzim Gamma GT, SGOT, dan SGPT dalam darah mengindikasikan adanya kebocoran seluler dan hilangnya integritas fungsional sel hepatosit (Rose, et al., 2014). Setelah asupan ekstrak etanol bit merah organik didapatkan adanya penurunan yang signifikan terhadap kadar enzim Gamma GT, SGOT dan SGPT pada kelompok IV, V dan VI dibandingkan kelompok kontrol positif (Kelompok III). Pada kelompok VI (Pestisida \& Ekstrak etanol bit $400 \mathrm{mg} / \mathrm{KgBB}$ ) terjadi penurunan enzim Gamma GT dua kali lipat (58\%), dan penurunan kadar enzim SGOT dan SGPT masing-masing 38\% dan $34 \%$ dibanding kelompok III. Anilisis statistik post hoc mendapatkan penurunan tersebut bermakna dengan $p$-value $=0,000(<0,05)$. Penurunan enzim terjadi secara berangsung-angsur seiring peningkatan kadar asupan ekstrak bit. Semakin tinggi dosis asupan ekstrak bit maka penurunan enzim transferase semakin besar. Aktivitas kadar enzim Gamma GT, SGOT dan SGPT kelompok VI kembali pulih mendekati level kontrol normal. Dapat dikatakan bahwa dosis asupan ekastrak etanol bit merah organik yang paling baik pada penelitian ini adalah $400 \mathrm{mg} / \mathrm{KgBB}$.

Hasil penelitian yang sejalan dengan penelitian ini adalah penelitian dari Rose, et al., (2014). Pada penelitian tersebut pemberian Karbon tetraclorida (CCL4) meningkatkan 3 kali lipat aktivitas alanine amino transferase (ALT), aspartate amino transferase (AST) dan bilirubin $(p$-value $<0,05)$ dibandingkan dengan nilai kontrol. Namun pemberian bit merah $300 \mathrm{mg} / \mathrm{Kg}$ BB berhasil memulihkan aktivitas alanine amino transferase (ALT), aspartate amino transferase (AST) dan bilirubin mendekati level normal. Pada penelitian tersebut dilakukan pengukuran fitokimia terhadap ekstrak metanol bit dan mendapatkan kandungan Total Phenolics Content (TPC) $26,47 \mathrm{mgGAE} / \mathrm{g}$ dan Total Flavonoids Content (TFC) sebesar 15,7QE/g (Rose, et al., 2014). Kandungan mineral dan vitamin pada bit merah; vit C $441 \mathrm{mg} / 100 \mathrm{~g}$, natrium $454 \mathrm{mg} / 100 \mathrm{~g}$, kalsium $385 \mathrm{mg} / 100 \mathrm{~g}$, besi $11,6 \mathrm{mg} / 100 \mathrm{~g}$, total abu 4,8g/100g, karoten dan tiamin sebanyak 32,6 dan $0,28 \mu \mathrm{g} / 100 \mathrm{~g}$, berdampak pada berbagai rute fisiologis yang melibatkan antioksidan non enzimatik. Ekstrak metanol bit merah mampu mempertahankan status fungsional normal hati setelah diinduksi CCL4., yang dibuktikan dengan tidak adanya nekrosis dan infiltrasi lemak pada hasil histologi hati tikus (Carrillo, et al., 2019).

Beetroot mengandung pigmen betalain yang terdiri dari betasianin (pewarnaan merah/violet) atau betaxanthin (pewarnaan kuning/oranye). Rata-rata kadar betalain pada beetroot organik antara 3,754 \pm 56 dan $11,932 \pm 304(\mathrm{mg} / \mathrm{kg})$ (Khan, 2016). Lee, et al., (2005), mengatakan betalain mempunyai kemampuan antiinflamatory, anti karsinogenik. Betalain bersifat chemoprefentive dengan menghambat 7-methoxyresorufin demethylase.

Penelitian lain yang sejalan dilaporkan oleh Krajka-Kuźniak, et.al. (2012) mendapatkan adanya peningkatan pada semua enzim liver sebanyak $37-538 \%$ setelah paparan hepatocarcinogenic N-nitrosodiethylamine (NDEA) $150 \mathrm{mg} / \mathrm{KgBB}$ terhadap hewan uji. Asupan jus beetroot $8 \mathrm{ml}$ selama 28 hari mampu menekan kerusakan DNA liver dari NDEN sebasar 20\%. Asupan jus beetroot mampu menurunan hampir semua enzim liver seperti alanine aminotransferase (ALT) 39\%, aspartate 
aminotransferase (AST) 8\%, alkaline phosphatase (ALP), gamma glutamyl transferase (GGT) $43 \%$ dan bilirubin $31 \%$. Aktivitas perlindungan jus akar bit merah terhadap kerusakan hati yaitu dengan menjaga integritas membran plasma menekan kebocoran enzim dan protein. Menurut Krajka-Kuźniak, et al. (2012) dan Guldiken, et al. (2016), pemberian ekstrak bit merah memberikan efek perbaikan terhadap abnormalitas fungsi hepar.

Bit merah mempunyai kemampuan menekan stres oksidatif yang diakibatkan racun pestisida, melalui aktivitas antioksidan fenolat, flavonoid, Vit E, Vit C, karoten dan thiamin. Kemampuan dari fenolat dikarenakan gugus hidroksil. Fenolat dan Flavonoid merupakan sekelompok senyawa poliphenol yang mempunyai kemampuan anti-hepatotoksik dan anti inflamasi. Kemampuannya dalam menangkal radikal bebas/Reactive Oxygen Species (ROS) dengan cara menghambat enzim aldosa reduktase dan xantin oksidase. Fenolat dan flavonoid merupakan fitokimia aktif di dalam buah bit merah (Georgiev, et al., 2010). Kadar betacyanin dan polyphenols beetroots yang ditanam secara organik lebih tinggi dibanding yang ditanam secara non organik. Penelitian Carillo, et al., (2017) mendapatkan kandungan betalain total

\section{DAFTAR PUSTAKA}

Badan Litbangkes RI. (2013). Laporan akhir riset khusus pencemaran lingkungan di kawasan pertanian kota. Jakarta.

Bendetti, D. (2014). An Evaluation of Occupational Exposures to Pesticides in Brazil. Occupational Medicine \& Health Affairs. 02(04). https://doi.org/10.4172/23296879.1000170

Carrillo, C., Rey, R., Hendrickx, M., del Mar Cavia, M., \& Alonso-Torre, S. (2017). Antioxidant Capacity of Beetroot: Traditional vs Novel Approaches. Plant Foods for Human Nutrition. 72(3), 266273. https://doi.org/10.1007/s11130-0170617-2

Carrillo, C., Wilches-Pérez, D., Hallmann, E., Kazimierczak, R., \& Rembiałkowska, E. (2019). Organic versus conventional beetroot. Bioactive compounds and antioxidant properties. $L w t, 116$ (December 2018), 108552. https://doi.org/10.1016/j.lwt.2019.108552

Clifford, T., Howatson, G., West, D. J., \& Stevenson, E. J. (2015). The potential pada bit organik $10,145 \pm 2,619 \mathrm{mg} / \mathrm{Kg}$ sedangkan bit non organic $6,949 \pm 2,576 \mathrm{mg} / \mathrm{Kg}$. Rata-rata bit organik mengandung betalain $32 \%$ lebih tinggi dibanding bit non organik. Kandungan polifenol bit organik 11,659 \pm 642 , sedangkan non organik $5,644 \pm 224 \mathrm{mg} / \mathrm{Kg}$. Bit organik mengandung polifenol 20-52\% lebih tinggi dibanding non organik (Carrillo, et al., 2019). Penelitian ini menggunakan bit merah organik, agar perbaikan terhadap abnormalitas faal hepar lebih baik. Pada penelitian ini terbukti pemberian ekstrak etanol bit merah organik selama 14 hari dengan dosis tertingi $400 \mathrm{mg} / \mathrm{Kg}$ BB mampu memperbaiki abnormalitas fungsi hepar dengan optimal, yang dibuktikan dengan peningkatan kembali enzim cholinesterase dan penurunan enzim gamma glutamil transferase (GGT), serum glutamic oxsaloasetic transaminase (SGOT) serta serum glutamic pyruvic transaminase (SGPT).

\section{SIMPULAN}

Bit merah (Beta vulgaris L) organik memiliki efek hepatoprotektif tehadap abnormalitas faal hepar akibat paparan pestisida dengan dosis optimal 400mg/Kg BB.

benefits of red beetroot supplementation in health and disease. Nutrients. https://doi.org/10.3390/nu7042801

Coles, L. T., \& Clifton, P. M. (2012). Effect of beetroot juice on lowering blood pressure in free-living, disease-free adults: A randomized, placebo-controlled trial. Nutrition Journal. 11(1), 1-6. https://doi.org/10.1186/1475-2891-11-106

El-Gengaihi, S. E., Hamed, M. A., Aboubaker, D. H., \& Mossa, A. T. H. (2016). Flavonoids from sugar beet leaves as hepatoprotective agent. International Journal of Pharmacy and Pharmaceutical Sciences. 8(4), 281-286.

Fantke, P., Friedrich, R., \& Jolliet, O. (2012). Health impact and damage cost assessment of pesticides in Europe. Environment International, $\quad 49, \quad 9-17$. https://doi.org/10.1016/j.envint.2012.08.001

Gangemi, S., Miozzi, E., Teodoro, M., Briguglio, G., De Luca, A., Alibrando, C., Polito, I., \& Libra, M. (2016). Occupational exposure to pesticides as a possible risk factor for the development of chronic diseases in humans (Review). Molecular 
Medicine Reports, 14(5), 4475-4488. https://doi.org/10.3892/mmr.2016.5817

Ganong W. (2008). Buku Ajar Fisiologi Kedokteran. Jakarta: EGC.

Georgiev, V. G., Weber, J., Kneschke, E. M., Denev, P. N., Bley, T., \& Pavlov, A. I. (2010). Antioxidant activity and phenolic content of betalain extracts from intact plants and hairy root cultures of the red beetroot Beta vulgaris cv. Detroit Dark Red. Plant Foods for Human Nutrition, 65(2),

105-111. https://doi.org/10.1007/s11130-010-0156-6

Guldiken, B., Toydemir, G., Nur Memis, K., Okur, S., Boyacioglu, D., \& Capanoglu, E. (2016). Home-processed red beetroot (Beta vulgaris L.) products: Changes in antioxidant properties and bioaccessibility. International Journal of Molecular Sciences, $17(6)$. https://doi.org/10.3390/ijms17060858

Guyton A.C., H. J. . (2014). Buku Ajar Fisiologi Kedokteran (12th ed.). Jakarta: EGC.

Hernández, A. F., Amparo Gómez, M., Pérez, V., García-Lario, J. V., Pena, G., Gil, F., López, O., Rodrigo, L., Pino, G., \& Pla, A. (2006). Influence of exposure to pesticides on serum components and enzyme activities of cytotoxicity among intensive agriculture farmers. Environmental Research. 102(1), 70-76.

https://doi.org/10.1016/j.envres.2006.03.002

Hoffbrand, A.V and Moss, A. H. (2016). Hoffbrand's Essential Haematology (7th ed.). Jakarta: EGC.

Ikawati, K., \& Rokhana. (2018). Pengaruh Buah Bit (Beta vulgaris) Terhadap Indek Eritrosit pada Remaja Putri dengan Anemia. Journal of Nursing and Public Health. 6(2), 60-66. https://jurnal.unived.ac.id/index.php/jnph/a rticle/view/659/570

Indhumathi, T., \& Kannikaparameswari, K. (2012). Hematopoietic study of the methanolic root extract of Beta vulgaris on albino rats-an in vivo study. Int J Pharm Biol Sci. 3(4), 1005-1015.

Kartika Y. (2012). Faktor Risiko Yang Berkaitan Dengan Kejadian Keracunan Pestisida Pada Petani Penyemprot Tanaman Bawang Merah Di Desa Sengon Kecamatan Tanjung Kabupaten Brebes. Unnes Journal of Public Health. 1(2).

Khan, D. A., Bhatti, M. M., Khan, F. A., Naqvi, S. T., \& Karam, A. (2008). Adverse effects of pesticides residues on biochemical markers in pakistani tobacco farmers.
International Journal of Clinical and Experimental Medicine. 1(3), 274-282. http://www.ncbi.nlm.nih.gov/pubmed/1907 9663\%0Ahttp://www.pubmedcentral.nih.g ov/articlerender.fcgi?artid=PMC2592591

Khan, M. I. (2016). Plant Betalains: Safety, Antioxidant Activity, Clinical Efficacy, and Bioavailability. Comprehensive Reviews in Food Science and Food Safety. 15(2),

316-330. https://doi.org/10.1111/1541-4337.12185

Kim, B. H., Jung, S. H., \& Jung, S. (2020). Beet root (Beta vulgaris) protects lipopolysaccharide and alcohol-induced liver damage in rat. Toxicological Research. 36(3), 275-282. https://doi.org/10.1007/s43188-019-00030-4 Krajka-Kuźniak, V., Szaefer, H., Ignatowicz, E., Adamska, T., \& Baer-Dubowska, W. (2012). Beetroot juice protects against Nnitrosodiethylamine-induced liver injury in rats. Food and Chemical Toxicology. 50(6), 2027-2033. https://doi.org/10.1016/j.fct.2012.03.062

Kumar, Y. (2015). Beetroot: A Super Food. Internal Journal of Engineering Studies and Technical Approach.

Lee, C. H., Wettasinghe, M., Bolling, B. W., Ji, L. L., \& Parkin, K. L. (2005). Betalains, phase II enzyme-inducing components from red beetroot (Beta vulgaris L.) extracts. Nutrition and Cancer. 53(1), 91-103. https://doi.org/10.1207/s15327914nc5301_11

Lionetto, M. G., Caricato, R., Calisi, A., Giordano, M. E., \& Schettino, T. (2013). Acetylcholinesterase as a biomarker in environmental and occupational medicine: New insights and future perspectives. BioMed Research International, 2013. https://doi.org/10.1155/2013/321213

Nemzer, B., Pietrzkowski, Z., Spórna, A., Stalica, P., Thresher, W., Michałowski, T., \& Wybraniec, S. (2011). Betalainic and nutritional profiles of pigment-enriched red beet root (Beta vulgaris L.) dried extracts. Food Chemistry. 127(1), 42-53. https://doi.org/10.1016/j.foodchem.2010.1 2.081

Ramírez-Santana, M., Farías-Gómez, C., ZúñigaVenegas, L., Sandoval, R., Roeleveld, N., Van der Velden, K., Scheepers, P. T. J., \& Pancetti, F. (2018). Biomonitoring of blood cholinesterases and acylpeptide hydrolase activities in rural inhabitants exposed to pesticides in the Coquimbo Region of Chile. PLoS ONE. 13(5), 1-19. https://doi.org/10.1371/journal.pone.0196084 
Rose, M. H., Sudha, P. N., \& Sudhakar, K. (2014). Effect of Antioxidants and Hepatoprotective Activities of Methanol. $5(6)$, 2546-2555. https://doi.org/10.13040/IJPSR.09758232.5(6).2536- 45

Shentema, M. G., Kumie, A., Bråtveit, M., Deressa, W., Ngowi, A. V., \& Moen, B. E. (2020). Pesticide use and serum acetylcholinesterase levels among flower farm workers in Ethiopia-a crosssectional study. International Journal of Environmental Research and Public Health, 17(3). https://doi.org/10.3390/ijerph17030964

Silvério, A. C. P., Machado, S. C., Azevedo, L., Nogueira, D. A., de Castro Graciano, M. M., Simões, J. S., Viana, A. L. M., \& Martins, I. (2017). Assessment of exposure to pesticides in rural workers in southern of Minas Gerais, Brazil. Environmental Toxicology and Pharmacology. $\quad 55, \quad 99-106$. https://doi.org/10.1016/j.etap.2017.08.013

Suripto I. (2017). Pemkab: Brebes Jadi Pengguna Pestisida Tertinggi se-ASEAN. Detik News, 1. https://news.detik.com/berita-jawatengah/d-3609497/pemkab-brebes-jadipengguna-pestisida-tertinggi-se-asean

Tsani, R., Setiani, O., \& Dewanti, N. (2017). Hubungan Riwayat Pajanan Pestisida Dengan Gangguan Fungsi Hati Pada Petani Di Desa Sumberejo Kecamatan Ngablak Kabupaten Magelang. Jurnal Kesehatan Masyarakat (e-Journal). 5(3), 411-419.

Wulandari, D. D., Santoso, A. P. R., \& Wulansari, D. D. (2019). The Effect of Beetroot (Beta vulgaris L.) Juice on Cholinesterase Activity in Farmers Exposed to Organophosphate Pesticides . Indonesian Journal of Medical Laboratory Science and Technology. 1(2), 80-87. https://doi.org/10.33086/ijmlst.v1i2.1215 